\title{
Spotted fever group rickettsiae transmitted by Dermacentor ticks and determinants of their spread in Europe
}

\author{
Weronika Buczek ${ }^{1, B, D, F \oplus}$, Agnieszka Koman-Iżko ${ }^{1, B-D, F \oplus}$, Alicja M. Buczek ${ }^{1, B, D \oplus}{ }^{\text {, Alicja Buczek }}{ }^{1, A, D-F \oplus}$, \\ Katarzyna Bartosik ${ }^{1, \mathrm{E}-\mathrm{F}}{ }^{\oplus}$, Dorota Kulina ${ }^{2, \mathrm{D}, \mathrm{F} \oplus}{ }^{\oplus}$, Dariusz Ciura ${ }^{3, \mathrm{D}, \mathrm{F}} \oplus$ \\ ${ }^{1}$ Chair and Department of Biology and Parasitology, Medical University, Lublin, Poland \\ ${ }^{2}$ Department of Basic Nursing and Medical Teaching, Medical University, Lublin, Poland \\ ${ }^{3}$ Department of Health Promotion and Treatment of Obesity, Medical University of Silesia, Katowice, Poland \\ A - Research concept and design, B - Collection and/or assembly of data, C - Data analysis and interpretation, \\ $D$ - Writing the article, E - Critical revision of the article, F - Final approval of article
}

Buczek W, Koman-Iżko A, Buczek AM, Buczek A, Bartosik K, Kulina D, Ciura D. Spotted fever group rickettsiae transmitted by Dermacentor ticks and determinants of their spread in Europe. Ann Agric Environ Med. 2020; 27(4): 505-511. doi: 10.26444/aaem/120602

\begin{abstract}
Rickettsiae from the spotted fever group, i.e. the etiological agents of tick-borne lymphadenopathy/Dermacentor-borne necrotic erythema and lymphadenopathy (TIBOLA /DEBONEL) syndrome, are associated with ticks, including Dermacentor marginatus and Dermacentor reticulatus. The expansion of these ticks into new areas increases the risk of infection of their hosts with tick-borne pathogens. The study summarises the importance of 2 species from the genus Dermacentor, i.e. D. marginatus and $D$. reticulatus, in the spread of spotted fever group rickettsiae in various regions of Europe. The study also focuses on the determinants of the presence of vectors and transmission of rickettsiae, as well as the effects of human infections with these pathogens. The climate changes observed nowadays affect vectors and increase the incidence and spread of tick-borne diseases worldwide. Due to the existing risk of exposure to an increasing number of people, knowledge about the course of these serious diseases and their etiological factors should be disseminated among healthcare professionals as well as in society. There is a great challenge for epidemiological services to provide access to medical and veterinary facilities in order to diagnose and treat rickettsioses. Therefore, the development of a strategy for tick control and the popularisation of knowledge concerning prophylaxis of tick-borne diseases is indispensable.
\end{abstract}

\section{Key words}

Rickettsia; spotted fever group rickettsiae; TIBOLA/DEBONEL; tick-borne diseases; Dermacentor reticulatus; Dermacentor marginatus

\section{INTRODUCTION}

Tick-borne rickettsioses are caused by various bacterial species from the genera Rickettsia, Ehrlichia, Neoehrlichia, and Anaplasma $[1,2,3,4]$. The greatest medical importance in this bacterial group is ascribed to spotted fever group rickettsiae (SFGR) (genus Rickettsia). The association of different rickettsia species with their hosts is determined by many factors, mainly the pathogen traits, the vector competence of tick species, and the presence of zoonotic reservoirs indispensable for the persistence of pathogens in a specific environment. The presented study analyses the role of Dermacentor ticks in the transmission of SFG rickettsiae in Europe, especially in its central and south parts, and the effects of infection with these pathogens in humans. The increase is emphasised in the risk of attacks by Dermacentor reticulatus and Dermacentor marginatus ticks on humans and animals related to climate and weather change, and human activity affecting the landscape and the structure of plants and animals, the latter of which are potential hosts of various developmental stages of these ticks.

Address for correspondence: Alicja Buczek, Chair and Department of Biology and Parasitology, Medical University, Poland

E-mail: alicja.buczek@umlub.pl

Received: 20.02.2020; accepted: 15.04.2020; first published: 07.05.2020
Spread of spotted fever group rickettsiae. SFGR are rodshaped bacteria with a size of $0.3-0.5 \times 0.8-2 \mu \mathrm{m}$ with trilaminar cell walls surrounded by a thick electron-lucent layer (halo zone) without flagella. As reported by Socolovschi et al. [5], as many as 16 out of the 25 Rickettsia species identified to-date may infect humans, and 13 species have been detected in the inhabitants of Europe. Species with confirmed pathogenicity and remarkable epidemiological importance include Rickettsia conorii subsp. conorii (agent of Mediterranean spotted fever, MSF), Rickettsia conorii subsp. israelensis (Israeli spotted fever, ISF), Rickettsia conorii subsp. caspia, Rickettsia conorii subsp. indica (Indian tick typhus), Rickettsia massiliae, Rickettsia monacensis (MSF-like illness), R. sibirica subsp. mongolitimonae (lymphangitis-associated rickettsiosis, LAR), Rickettsia slovaca and Rickettsia raoultii (SENLAT- scalp eschars and neck lymphadenopathy, formerly referred to as TIBOLA- tickborne lymphadenopathy or DEBONEL-Dermacentor-borne necrotic erythema and lymphadenopathy), Rickettsia aeschlimannii (symptoms similar to those of MSF), Rickettsia helvetica, and R. sibirica subsp. sibirica $[6,7,8,9,10,11]$. In central Europe, 5 Rickettsia species have been detected in ticks: $R$. slovaca, $R$. raoultii, $R$. helvetica, $R$. monacensis, and Candidatus Rickettsia mendelii $[12,13]$. With the exception of $R$. mendelii, all these species have been identified in $D$. marginatus and D. reticulatus (Fig. 1). 


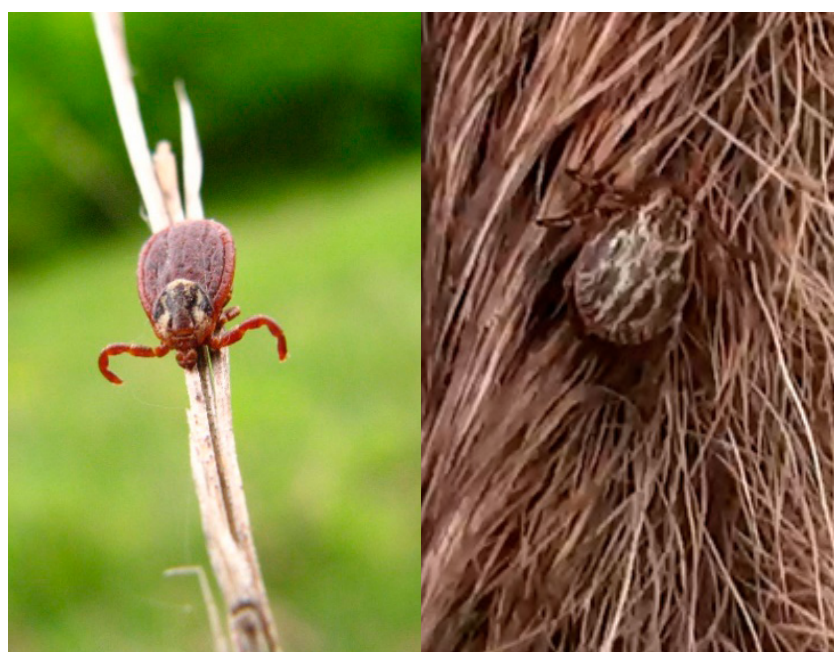

Figure 1. Dermacentor reticulatus: (a) female, (b) male

SFGR have been detected in ticks from the genus Dermacentor across Europe, from the UK [14], Denmark [15], The Netherlands [16], and the Baltic countries [17] in the north, through countries in the western $[8,18,19]$, central [20-30], and eastern parts [8,31-34] and Spain [35], Portugal [36-38], Italy [39-43], Greece [44], and Croatia [45] in the south. In Poland, the presence of SFG rickettsiae in D. reticulatus has been documented in many regions of the country [46-53].

Ticks are infected with rickettsiae while feeding on a host with rickettsiosis. Within the tick population, rickettsiae are disseminated via transovarial $[5,33,54,55]$, transstadial $[5,33]$ and, probably less frequently, transspermal [56] transmission. The possibility of transmission of SFGR $R$. massiliae and $R$. rickettsii during the co-feeding of ixodid ticks has also been suggested [5].

In natural conditions, rickettsiae may be transferred in another way. The phenomenon of oral-anal contact between two D. reticulatus and Ixodes ricinus ticks, described recently for the first time, may indicate an alternative route of transmission of some pathogenic and non-pathogenic microorganisms from one population of sympatric tick species to another [57]. The scale of this type of interspecific tick contacts in natural conditions and their epidemiological importance are as yet unknown and require further investigations. The possibility of transmission of rickettsiae during the feeding of hungry or not fully engorged specimens on engorged ticks from the same species, also needs elucidation. Such research is even more advisable as hyperparasitism has been described in various ticks, including those with great epidemiological importance [58]. It has been experimentally shown that some pathogens, such as Dipetalonema viteae, Borrelia crocidurae and Borrelia burgdorferi s.l., can be transmitted during parasitization of some ticks by others [59-61].

As in the case of other tick-borne pathogens, the prevalence of rickettsiae in ticks differs between regions and between different years in the regions. In the northern regions, $D$. reticulatus occurrence varies, with the prevalence of $R$. raoultii in adult ticks varying from $0 \%-36.9 \%$ (mean $4.9 \%$ ) in different parts of Lithuania and Latvia [17]. In Belarus, as many as $41.9 \%$ of $D$. reticulatus specimens collected from animals and $44.5 \%$ of these ticks found on vegetation were infected with Rickettsia spp., with the dominance of R. raoultii $35.5 \%$ and $22.6 \%$ in specimens collected from animals and vegetation, respectively) [34]. Higher SFGR infection rates in Dermacentor ticks have been reported from many localities in central and southern Europe.

In recreational areas in Białowieża (Podlaskie Province, north-eastern Poland), $R$. raoultii DNA was detected in $56.7 \%$ of $D$. reticulatus specimens collected from vegetation [47]. Later, Stańczak et al. [53] identified rickettsial DNA in $41 \%$ of adult $D$. reticulatus in this province. In Lublin Province (eastern Poland), the SFGR prevalence in this species during the study period was 53.0\% [49]. Dermacentor reticulatus ticks from Łęczyńsko-Włodawskie Lakeland (Lublin Province) have been most frequently diagnosed with R. raoultii infection (43.8\%) [52]. In the endemic regions of north-eastern (Warmińsko-Mazurskie Province) and central Poland (Mazowieckie Province), Rickettsia spp. were identified in $44.1 \%$ of $D$. reticulatus [50]. A higher percentage of SFGR (60\%) was detected in adult stages of the species collected from dogs and cats in the Wrocław agglomeration [51].

Infection with SFG rickettsiae has been detected in $85.15 \%$ and $97.0 \%$ of D. marginatus ticks in southern and northern Spain, respectively [62, 63]. In Slovakia during 2004 - 2010, the infection rate ranged from $25.49 \%-36.17 \%$ depending on the tick collection. The prevalence of $R$. raoultii was 8.1 $-8.6 \%$ and $22.3-27 \%$ in D. marginatus and D. reticulatus, respectively. In turn, the prevalence of $R$. slovaca was higher in D. marginatus $(20.6-24.3 \%)$ than in D. reticulatus $(1.7$ - 3.4\%) [26]. In hunting and recreational forest areas in southern Hungary, R. raoultii infection has been confirmed in $58 \%$ of examined $D$. reticulatus specimens [30]. A high prevalence of Rickettsia spp. (70.5\%) in questing D. reticulatus and only $11.4 \%$ cases of $I$. ricinus have been reported from Saxony (Germany) [64]. As in the case of D. reticulatus, the infection rate in D. marginatus varied widely from $0.7 \%$ $13.3 \%$ in Germany [24, 25], 32.1\% in Italy [40] and $41.5 \%$ in Portugal [37].

Particularly noteworthy is the fact that SGFR are transferred into new areas together with the spread of Dermacentor ticks into urban and suburban areas. In a Kiev city park (Ukraine), $10.1 \%$ of $D$. reticulatus ticks were infected by R. raoultii [65]. As many as $36 \%$ of ticks collected in a park in Rome (Italy), including $14 \%$ of D. marginatus, $26 \%$ of Rhipicephalus turanicus, and $70 \%$ of I. ricinus, exhibited the presence of rickettsial DNA. D. marginatus were also found to be infected by R. monacensis [43]. SFGR may co-infect $D$. reticulatus ticks with other pathogens, i.e. TBE virus, Anaplasma phagocytophilum, B. burgdorferi, Babesia spp., or Toxoplasma gondii [52]. Ticks can also be infected by 2 SFG Rickettsia species. In Croatia, the coexistence of $R$. helvetica and $R$. slovaca was noted in $1 \%$ of D. reticulatus ticks [45]. Coinfections of SFGR (R. slovaca and R. helvetica) with Borrelia lusitaniae were also found in ticks, including D. marginatus (23.3\%), collected in a Safari Park in Alentejo (Portugal) [37].

The circulation of Rickettsia spp. in nature proceeds with the participation of vectors - ticks and hosts of their juvenile and adult stages [66-70]. Larvae and nymphs of D. reticulatus and D. marginatus ticks parasitize small rodents and insectivores, while adult stages feed on medium-sized and large animals. $R$. raoultii has also been detected in blood collected $24 \mathrm{~h}$ after $D$. reticulatus was placed in feeding units [71]. In Slovakia, $11 \%$ of small mammals are infected by SFG rickettsiae [70]. The dominant species is $R$. helvetica, which has been detected most frequently in the striped field mouse 
(Apodemus agrarius), the yellow-necked mouse (Apodemus flavicollis), the bank vole (Myodes glareolus), and the common vole (Microtus arvalis) in natural and suburban habitats. In turn, $R$. felis was identified in A. flavicollis captured in a suburban habitat. R. slovaca was detected in one A. flavicollis captured in a natural habitat. The highest species diversity of rickettsiae was observed in A. flavicollis, and the highest prevalence of the bacteria was recorded in M. glareolus [6669]. The prevalence of Rickettsia spp. in the investigated small mammals (A. agrarius, A. flavicollis, M. arvalis, M. agrestis, Mustela nivalis, M. glareolus, Sorex araneus, and Talpa europaea) from Germany (Saxony) was 25.3\% [64].

The strong relationship between rickettsiae and host species is supported by the 7-fold higher prevalence of Rickettsia spp. in M. glareolus infested with D. reticulatus than that in noninfested animals. In south-western Poland, DNA of SFG rickettsiae was detected in tissues of $17.6 \%$ of wild-living rodents - A. agrarius, A. flavicollis, and M. glareolus [72]. Some of the hosts of $D$. reticulatus and $D$. marginatus adult stages, i.e. wild and domestic large ungulates, carnivores, horses, or wild boars, can also be reservoirs of rickettsiae in nature $[40,51,73,74]$.

Analyses of mammalian biological material for the presence of the DNA of SFG rickettsiae and/or antibodies against pathogens have confirmed the widespread distribution and high prevalence of rickettsiae in Dermacentor spp. hosts in the European occurrence range of these ticks [51, 74-76]. For instance, high seroprevalence of $R$. slovaca in Spain was recorded in domestic ruminants $-65 \%$ in bullfighting cattle, $21 \%$ in goats, and $16 \%$ in sheep [77].

Ticks infected by SFG rickettsiae can invade humans and feed on the new host, which poses a high risk of transmission of the pathogens during blood ingestion. Cases of tick-borne lymphadenopathy (TIBOLA) caused by $R$. slovaca have been reported in patients who had contact with horses [78]. Humans can be infected not only by a feeding Dermacentor female tick, but also by a foraging male specimen [78, 79].

Impact of environmental factors on Dermacentor ticks and transmission of SFG rickettsiae. Climate change leading to global warming alters tick fauna in various habitats and the structure of animals, i.e. potential hosts of various tick development stages and animal reservoirs of pathogens. Examples of species with high dynamics of expansion in the last 10 years include $D$. reticulatus [80-83] and D. marginatus [84-86]. These ticks migrate with their hosts via ecological routes along rivers. The transfer of $D$. reticulatus ticks with hosts is the quickest route of extension of the occurrence range of this species. D. reticulatus females and males alone are able to move at a distance of $66.35 \pm 100 \mathrm{~cm}$ and $54.85 \pm 45 \mathrm{~cm}$ over 7 weeks, respectively [87]. Studies conducted on other tick species suggest that pathogens may influence the physical activity of ticks. It has been demonstrated that Rickettsia increase and Arsenophonus limit the locomotor activity of larvae of 3 tick species, i.e. Amblyomma americanum, Dermacentor variabilis, and Ixodes scapularis, which are pathogen vectors in eastern North America [88]. The presence of Rickettsia bacteria in D. variabilis ticks affect their behaviour [89].

Twenty years ago in Poland, D. reticulatus ticks were found only in the eastern and north-eastern parts of the country [90-92]. Currently, tick localities are reported from many other places in the eastern $[92,93]$, central and north- eastern [94-97] western [98-100], and in south-western [101] provinces. In Europe, a similar trend towards expansion of the occurrence range is observed in other species with great epidemiological importance [102].

Due to the climate and weather changes, adult D. reticulatus stages in central Europe can attack hosts even during winter [103]. Active specimens were found in January in the habitat of this species in eastern Poland, which is usually a diapause period for these ticks. Similarly, $D$. reticulatus activity in winter has been reported from western Poland [104]. Besides the expansion of the occurrence range of Dermacentor ticks in Europe, their population size is also increasing. Over 10 years, the number of $D$. reticulatus adults in a meadow ecosystem used for grazing cattle in eastern Poland has increased twoand three-fold in spring and autumn, respectively [105]. The dynamics of the seasonal activity of this species with 2 peaks, in spring and autumn, and a period of decline in the activity in July persists in central Europe. However, the beginning of spring activity and the end of autumn activity shift in time together with the climate change [106]. Depending on the temperature, ticks can attack hosts already at the end of the calendar winter and in early spring. Favourable weather conditions contribute to the prolongation of the autumn activity of $D$. reticulatus. The risk of pathogen infection of hosts is increased at the peak of tick diurnal activity. In eastern Poland, adult $D$. reticulatus stages exhibit the highest activity from 12.00 midday - 16.25 in spring and from 10.00 a.m. -18.25 in autumn, with a peak at $14.00-14.25$ in both these periods [107].

The behaviour of ticks during the parasitic phase can be modified when 2 species coexist on the same host. During $D$. reticulatus and D. marginatus co-feeding on the same host, 2 inter-specific systems with different physiological features are formed, which may influence the transmission of tickborne pathogens. In the inter-specific group, D. marginatus females attach to the host for a longer time, and although their feeding time is shorter than in a mono-specific group, feeding efficiency does not decrease [108]. The current study demonstrates that the co-feeding of I. ricinus and D. reticulatus ticks on the same host influences their nonparasitic stage of the life cycle by increasing significantly the egg amount and hatching success in I. ricinus feeding in inter-specific groups [109]. Additionally, the dynamics of tick feeding on hosts changes with the intensity of invasion [110] and tick gender structure [111].

Human infection with SFG rickettsiae. Human infections with SFG rickettsiae have been reported from various European countries, in particular from those located in the southern and central parts of the continent. As many as 8 species of different spotted fever group (SFG) rickettsiae, i.e. R. slovaca, Rickettsia sp. IRS3/IRS4, R. massiliae/Bar29, R. aeschlimannii, Rickettsia sp. RpA4/DnS14, R. helvetica, Rickettsia sp. DmS1, and R. conorii, were identified in 10 species of ticks infesting humans in north-western Spain [35]. R. slovaca, R. raoultii, and $R$. roji transmitted by $D$. marginatus and/or D. reticulatus are the agents of TIBOLA (tickborne lymphadenopathy) or DEBONEL (Dermacentorborne necrotic erythema and lymphadenopathy) syndromes, which are also referred to as SENLAT, and reflects their clinical symptoms. The first case of $R$. slovaca infection following a tick bite was described in 1980. The patient was diagnosed with acute meningoencephalitis, febrile 
relapses, and prolonged persistence of neurasthenic disorders [112]. The next case of $R$. slovaca infection in humans was documented in 1997 in a patient in France [113]. Human infection with R. slovaca was also diagnosed in, e.g. Slovakia, Bulgaria, Hungary, Germany, Italy, Spain and Portugal [9, $38,39,114-118]$. Cases of human $R$. raoultii infections have also been reported from several other countries, e.g. France, Slovakia and Poland $[116,118,119]$. In Poland, Rickettsia spp. were detected for the first time in a patient with TIBOLA/ DEBONEL symptoms in Warsaw [120].

SFG rickettsiae introduced with tick saliva during feeding enter human blood. Via interaction between the adhesive protein $(\mathrm{OmpB})$, which is an abundant surface protein in Rickettsia, and Ku70 receptors in host cells, rickettsiae penetrate the vascular endothelial cells and are divided in the cell cytosol. Since rickettsiae penetrate other cells without passing through the intracellular space, they avoid the immune response. This promotes the spread of the infection in the organism. Most of the clinical symptoms caused by SFG rickettsiae are attributed to disseminated endothelial infection. Rickettsia spp. and other intracellular microorganisms have been identified in pathological aortic valves in humans [121]. Rickettsial infection results in increased microvascular permeability, generalised vascular inflammation, oedema, and release of vasoactive mediators, which exert an effect on coagulation and promote the release of pro-inflammatory cytokines.

The presence of antibodies against tick-borne SFG rickettsiae was detected in $36.0 \%$ of inhabitants of areas with a high risk of tick attacks in eastern Poland. In groups exposed to contact with ticks occupationally, antibodies against tick-borne SFG rickettsiae were confirmed in 50.7\% of forestry workers and $21.3 \%$ of agriculture workers [122]. In Catalonia (north-eastern Spain), the seroprevalence of $R$. slovaca in the general population was reported to range from $3.7 \%-5.5 \%$ [123], whereas in a group exposed to tick bites seroprevalence was as high as $16.9 \%$ [124].

Tick-borne rickettsioses (TBR) in humans may be asymptomatic [125], but usually with moderate symptoms [3, $9,125]$. However, deaths of patients have also been reported $[9,38]$.

The length of the TIBOLA/DEBONEL incubation time varies from 1 - 15 days (typically between 5 - 10 days). The most common symptoms of $R$. slovaca infection include asthenia, headache, painful adenopathies, painful scalp eschar, and oedema of lymph nodes close to the tick bite. Low fever, and rarely rash, as well as face oedema may develop in patients. Symptoms of SENLAT syndrome may also include inoculation eschar, cervical lymphadenopathy, high fever, malaise, and headaches [6, 38, 115-117, 126]. Alopecia around the eschar persisting for a long time (several months), even after antibiotic therapy, has been reported [116]. Clinical symptoms of $R$. raoulti-induced TIBOLA syndrome are similar to those of $R$. slovaca infection, except for the absence of alopecia.

There are known cases of an emerging syndrome of scalp eschar and neck lymphadenopathy after a tick bite [127]. SFGRs can cause chronic symptoms in patients. Nillson et al. [128] reported the occurrence of $R$. helvetica in a patient with chronic perimyocarditis and suggested that the pathogen may play an important role in its etiology.

Due to the colonisation of new areas by $D$. marginatus and $D$. reticulatus, which are the main SFGR vectors in Europe, the risk of human and animal infections (including companion animals such as dogs and cats) with these rickettsiae and other tick-borne pathogens is increasing. The challenge for medical and epidemiological services is therefore to provide access to medical and veterinary facilities in order to diagnose and treat rickettsioses. Development of a strategy for tick control and popularisation of prophylaxis of tick-borne diseases are also indispensable.

\section{REFERENCES}

1. Raoult D, Roux V. Rickettsioses as paradigms of new or emerging infectious diseases. Clin Microbiol Rev. 1997; 10(4): 694-719.

2. Raoult D, Lakos A, Fenollar F, Beytout J, Brouqui P, Fournier PE. Spotless rickettsiosis caused by Rickettsia slovaca and associated with Dermacentor ticks. Clin Infect Dis. 2002; 34(10): 1331-1336. https:// doi.org/10.1086/340100

3. Parola P, Paddock CD, Raoult D. Tick-borne rickettsioses around the word: emerging diseases challenging old concepts. Clin Microbiol Rev. 2005; 18(4): 719-756. https://doi.org/10.1128/CMR.18.4

4. Brites-Neto J, Duarte KM, Martins TF. Tickborne infections in human and animal population worldwide. Vet World. 2015; 8(3): 301-315.

5. Socolovschi C, Mediannikov O, Raoult D, Parola P. The relationship between spotted fever group Rickettsiae and ixodid ticks. Vet Res. 2009; 40(2): 34

6. Lakos A. Tick-borne lymphadenopathy-a new rickettsial disease? Lancet 1997; 350(9083): 1006. https://doi.org/10.1016/S0140-6736(05)64072-X.

7. Raoult D, Berbis P, Roux V, Xu W, Maurin M. A new tick-transmitted disease due to Rickettsia slovaca. Lancet 1997; 350(9071): 112-113.

8. Mediannikov O, Matsumoto K, Samoylenko I, Drancourt M, Roux V, Rydkina E, Davoust B, Tarasevich I, Brouqui P, Fournier PE. Rickettsia raoultii sp. nov., a spotted fever group rickettsia associated with Dermacentor ticks in Europe and Russia. Int J Syst Evol Microbiol. 2008; 58(7): 1635-1639. https://doi.org/10.1099/ijs.0.64952-0

9. Oteo JA, Portillo A. Tick-borne rickettsioses in Europe. Ticks Tick Borne Dis. 2012; 3(5-6): 271-278. https://doi.org/10.1016/j.ttbdis.2012.10.035

10. Madeddu G, Mancini F, Caddeo A, Ciervo A, Babudieri S, Maida I, Fiori ML, Rezza G, Mura MS. Rickettsia monacensis as cause of Mediterranean spotted fever-like illness, Italy. Emerg Infec Dis. 2012; 18(4): 702-704. https://doi.org/10.3201/eid1804.111583

11. Parola P, Paddock CD, Socolovschi C, Labruna MB, Mediannikov O, Kernif T, Abdad MY, Stenos J, Bitam I, Fournier P-E, Raoult D. Update on Tick-Borne Rickettsioses around the World: a Geographic Approach. Clin Microbiol Rev. 2013; 26(4): 657-702.

12. Hajduskova E, Literak I, Papousek I, Costa FB, Novakova M, Labruna MB, Zdrazilova-Dubska L. 'Candidatus Rickettsia mendelii', a novel basal group rickettsia detected in Ixodes ricinus ticks in the Czech Republic. Ticks Tick Borne Dis. 2016; 7(3): 482-486. https://doi. org/10.1016/j.ttbdis.2016.02.004

13. Kowalec M, Szewczyk T, Welc-Falęciak R, Siński E, Karbowiak G, Bajer A. Rickettsiales Occurrence and Co-occurrence in Ixodes ricinus Ticks in Natural and Urban Areas. Microb. Ecol. 2019; 77(4): 890-904. http:// doi.org/doi:10.1007/s00248-018-1269-y

14. Tijsse-Klasen E, Jameson LJ, Fonville M, Leach S, Sprong H, Medlock JM. First detection of spotted fever group rickettsiae in Ixodes ricinus and Dermacentor reticulatus ticks in the UK. Epidemiol Infect. 2011; 139(4): 524-529.

15. Klitgaard K, Chriél M, Isbrand A, Jensen TK, Bødker R. Identification of Dermacentor reticulatus ticks carrying Rickettsia raoultii on migrating jackal, Denmark. Emerg Infect Dis. 2017; 23(12): 2072-2074. https:// dx.doi.org/10.3201/eid2312.170919

16. Nijhof AM, Bodaan C, Postigo M, Nieuwenhuijs H, Opsteegh M, Franssen L, Jebbink F, Jongejan F. Ticks and associated pathogens collected from domestic animals in the Netherlands. Vector Borne Zoonotic Dis. 2007; 7(4): 585-595.

17. Radzijevskaja J, Paulauskas A, Aleksandraviciene A, Jonauskaite I, Stanko M, Karbowiak G, Petko B. New records of spotted fever group rickettsiae in Baltic region. Microbes Infect. 2015; 17(11-12): 874-878. https://doi.org/10.1016/j.micinf.2015.09.006

18. Beati L, Finidori JP, Raoult D. First isolation of Rickettsia slovaca from Dermacentor marginatus in France. Am J Trop Med Hyg. 1993; 48(2): 257-268.

19. Bonnet S, de la Fuente J, Nicollet P, Liu X, Madani N, Blanchard B, Maingourd C, Alongi A, Torina A, Fernández de Mera IG, Vicente J, 
Weronika Buczek, Agnieszka Koman-Iżko, Alicja M. Buczek, Alicja Buczek, Katarzyna Bartosik, Dorota Kulina, Dariusz Ciura. Spotted fever group rickettsiae transmitted by...

George JC, Vayssier-Taussat M, Joncour G. Prevalence of tick-borne pathogens in adult Dermacentor spp. ticks from nine collection sites in France. Vector Borne Zoonotic Dis. 2013; 13(4): 226-236. https:// doi.org/10.1089/vbz.2011.0933

20. Řeháček J. Rickettsia slovaca, the organism and its ecology. Acta Scient Nat Acad Sci Bohemoslovacae Brno. 1984; 18: 1-50.

21. Řeháček J. Ecological relationships between ticks and rickettsiae. Eur J Epidemiol. 1989; 5(4): 407-413.

22. Dautel H, Dippel C, Oehme R, Hartelt K, Schettler E. Evidence for an increased geographical distribution of Dermacentor reticulatus in Germany and detection of Rickettsia sp. RpA4. Int J Med Microbiol. 2006; 296(Suppl. 1): 149-156.

23. Smetanová K, Schvarzová K, Kocianová E. Detection of Anaplasma phagocytophilum, Coxiella burnetii, Rickettsia spp., and Borrelia burgdorferi s.l. in ticks and wild-living animals in western and middle Slovakia. Ann NY Acad Sci. 2006; 1078: 312-315.

24. Pluta S, Tewald F, Hartelt K, Oehme R, Kimmig P, Mackenstedt U. Rickettsia slovaca in Dermacentor marginatus ticks, Germany. Emerg Infect Dis. 2009; 15(12): 2077-2078. https://doi.org/10.3201/ eid1512.090843

25. Silaghi C, Hamel D, Thiel C, Pfister K, Pfeffer M. Spotted fever group rickettsiae in ticks, Germany. Emerg Infect Dis. 2011; 17(5): 890-892.

26. Špitalská E, Štefanidesová K, Kocianová E, Boldiš V. Rickettsia slovaca and Rickettsia raoultii in Dermacentor marginatus and Dermacentor reticulatus ticks from Slovak Republic. Exp Appl Acarol. 2012; 57(2): 189-197. https://doi.org/10.1007/s10493-012-9539-8

27. Duscher GG, Hodžić A, Weiler M, Vaux AGC, Rudolf I, Sixl W, Medlock JM, Versteirt V, Hubálek Z. First report of Rickettsia raoultii in field collected Dermacentor reticulatus ticks from Austria. Ticks Tick Borne Dis. 2016; 7(5): 720-722. http://dx.doi.org/10.1016/j.ttbdis.2016.02.022

28. Ionita M, Silaghi C, Mitrea IL, Edouard S, Parola P, Pfister K. Molecular detection of Rickettsia conorii and other zoonotic spotted fever group rickettsiae in ticks, Romania. Ticks Tick Borne Dis. 2016; 7(1): 150-153. https://doi.org/10.1016/j.ttbdis.2015.10.006

29. Rudolf I, Venclíková K, Blažejová H, Betášová L, Mendel J, Hubálek $\mathrm{Z}$, Parola P. First report of Rickettsia raoultii and Rickettsia helvetica in Dermacentor reticulatus ticks from the Czech Republic. Ticks Tick Borne Dis. 2016; 7(6): 1222-1224. https://doi.org/10.1016/j. ttbdis.2016.07.011

30. Szekeres S, van Leeuwen AD, Rigó K, Jablonszky M, Majoros G, Sprong H, Földvári G. Prevalence and diversity of human pathogenic rickettsiae in urban versus rural habitats, Hungary. Exp Appl Acarol. 2016; 68(2): 223-226.

31. Rydkina E, Roux V, Rudakov N, Gafarova M, Tarasevich I, Raoult D. New Rickettsiae in ticks collected in territories of the Former Soviet Union. Emerg Infect Dis. 1999; 5(6): 811- 814.

32. Brouqui P, Parola P, Fournier PE, Raoult D. Spotted fever rickettsioses in southern and eastern Europe. FEMS Immunol Med Microbiol. 2007; 49(1): 2-12.

33. Samoylenko I, Shpynov S, Raoult D, Rudakov N, Fournier P-E. Evaluation of Dermacentor species naturally infected with Rickettsia raoultii. Clin Microbiol Infect. 2009; 15 (Suppl 2): 305-306. https:// doi.org/10.1111/j.1469-0691.2008.02249.x

34. Reye AL, Stegniy V, Mishaeva NP, Velhin S, Hübschen JM, Ignatyev G, Muller CP. Prevalence of tick-borne pathogens in Ixodes ricinus and Dermacentor reticulatus ticks from different geographical locations in Belarus. PLoS One 2013; 8(1): e54476. https://doi.org/10.1371/journal. pone. 0054476

35. Fernandez-Soto P, Perez-Sanchez R, Alamo-Sanz R, Encinas-Grandes A. Spotted fever group rickettsiae in ticks feeding on humans in northwestern Spain: is Rickettsia conorii vanishing? Ann NY Acad Sci. 2006; 1078: 331-333.

36. Márquez FJ. Spotted fever group Rickettsia in ticks from southeastern Spain natural parks. Exp Appl Acarol. 2008; 45(3-4): 185-194.

37. Milhano N, de Carvalho IL, Alves AS, Arroube S, Soares J, Rodriguez P, Carolino M, Núncio MS, Piesman J, de Sousa R. Coinfections of Rickettsia slovaca and Rickettsia helvetica with Borrelia lusitaniae in ticks collected in a Safari Park, Portugal. Ticks Tick Borne Dis. 2010; 1(4): 172-177. https://doi.org/10.1016/j.ttbdis.2010.09.003

38. de Sousa R, Pereira BI, Nazareth C, Cabral S, Ventura C, Crespo P, Marques N, da Cunha S. Rickettsia slovaca Infection in Humans, Portugal. Emerg Infect Dis. 2013; 19(10): 1627-1629. https://dx.doi. org/10.3201/eid1910.130376

39. Selmi M, Bertolotti L, Tomassone L, Mannelli A. Rickettsia slovaca in Dermacentor marginatus and tick-borne lymphadenopathy, Tuscany, Italy. Emerg Infect Dis. 2008; 14(5): 817-820. https://doi.org/10.3201/ eid1405.070976
40. Selmi M, Martello E, Bertolotti L, Bisanzio D, Tomassone L. Rickettsia slovaca and Rickettsia raoultii in Dermacentor marginatus ticks collected on wild boars in Tuscany, Italy. J Med Entomol. 2009; 46(6): 1490-1493.

41. Masala G, Chisu V, Satta G, Socolovschi C, Raoult D, Parola P. Rickettsia slovaca from Dermacentor marginatus ticks in Sardinia, Italy. Ticks Tick Borne Dis. 2012; 3(5-6): 393-395.

42. Martello E, Selmi M, Ragagli C, Ambrogi C, Stella MC, Mannelli A, Tomassone L. Rickettsia slovaca in immature Dermacentor marginatus and tissues from Apodemus spp. in the northern Apennines, Italy. Ticks Tick Borne Dis. 2013; 4(6): 518-521. https://doi.org/10. 1016/j. ttbdis.2013.07.002

43. Mancini F, Ciccozzi M, Lo Presti A, Cella E, Giovanetti M, Di Luca M, Toma L, Bianchi R, Khoury C, Rezza G, Ciervo A. Characterization of spotted fever group Rickettsiae in ticks from a city park of Rome, Italy. Ann Ist Super Sanita. 2015; 51(4): 284-290. https://doi.org/10.4415/ ANN_15_04_07

44. Psaroulaki A, Ragiadakou D, Kouris G, Papadopoulos B, Chaniotis B, Tselentis Y. Ticks, tick-borne rickettsiae, and Coxiella burnetii in the Greek Island of Cephalonia. Ann NY Acad Sci. 2006; 1078: 389-399.

45. Dobec M, Golubic D, Punda-Polic V, Kaeppeli F, Sievers M. Rickettsia helvetica in Dermacentor reticulatus ticks. Emerg Infect Dis. 2009; 15(1): 98-100. https://doi.org/ 10.3201/eid1501.080815

46. Stańczak J. Detection of spotted fever group (SFG) rickettsiae in Dermacentor reticulatus (Acari: Ixodidae) in Poland. Int J Med Microbiol. 2006; 296(Suppl 1): 144-148. https://doi.org/10.1016/j.ijmm.2006.01.014

47. Chmielewski T, Podsiadly E, Karbowiak G, Tylewska-Wierzbanowska S. Rickettsia spp. in ticks, Poland. Emerg Infect Dis. 2009; 15: 486-488. https://doi.org/ 10.3201/eid1503.080711

48. Matsumoto K, Grzeszczuk A, Brouqui P, Raoult D. Rickettsia raoultii and Anaplasma phagocytophilum in Dermacentor reticulatus ticks collected from Bialowieza Primeval Forest European bison (Bison bonasus bonasus), Poland. Clin Microbiol Infect. 2009; 15(Suppl 2): 286-287.

49. Wójcik-Fatla A, Cisak E, Zając V, Sroka J, Sawczyn A, Dutkiewicz J. Study on tick-borne rickettsiae in eastern Poland. I. Prevalence in Dermacentor reticulatus (Acari: Amblyommidae). Ann Agric Environ Med. 2013; 20(2): 276-279.

50. Mierzejewska EJ, Pawełczyk A, Radkowski M, Welc-Falęciak R, Bajer A. Pathogens vectored by the tick, Dermacentor reticulatus, in endemic regions and zones of expansion in Poland. Parasit Vectors. 2015; 8: 490. https://doi.org/10.1186/s13071-015-1099-4

51. Król N, Obiegala A, Pfeffer M, Lonc E, Kiewra D. Detection of selected pathogens in ticks collected from cats and dogs in the Wrocław Agglomeration, South-West Poland. Parasit Vectors. 2016; 9: 351. https://doi.org/10.1186/s13071-016-1632-0

52. Zając V, Wójcik-Fatla A, Sawczyn A, Cisak E, Sroka J, Kloc A, Zając Z, Buczek A, Dutkiewicz J, Bartosik K. Prevalence of infections and coinfections with 6 pathogens in Dermacentor reticulatus ticks collected in eastern Poland. Ann Agric Environ Med. 2017; 24(1): 26-32.

53. Stańczak J, Biernat B, Racewicz M, Zalewska M, Matyjasek A. Prevalence of different Rickettsia spp. in Ixodes ricinus and Dermacentor reticulatus ticks (Acari: Ixodidae) in north-eastern Poland. Ticks Tick Borne Dis. 2018; 9(2): 427-434. doi.org/10.1016/j.ttbdis.2017.12.010

54. Macaluso KR, Sonenshine DE, Ceraul SM, Azad AF. Infection and transovarial transmission of rickettsiae in Dermacentor variabilis ticks acquired by artificial feeding. Vector Borne Zoonotic Dis. 2004; 1(1): 45-53. https://doi.org/10.1089/153036601750137660

55. Moore TC, Pulscher LA, Caddell L, von Fricken ME, Anderson BD, Gonchigoo B, Gray GC. Evidence for transovarial transmission of tick-borne rickettsiae circulating in Northern Mongolia. PLoS Negl Trop Dis. 2018; 12(8): e0006696. https://doi.org/10.1371/journal. pntd.0006696

56. Hayes SF, Burgdorfer W, Aeschlimann A. Sexual transmission of spotted fever group rickettsiae by infected male ticks detection of rickettsiae in immature spermatozoa of Ixodes ricinus. Infect Immun. 1980; 27(2): 638-642.

57. Buczek A, Bartosik K, Buczek W, Buczek AM, Kulina D, Kulisz J, Tomasiewicz K. A unique phenomenon of oral-anal contact between ticks observed in two tick species Ixodes ricinus and Dermacentor reticulatus. Ann Agric Environ Med. 2018; 25(4): 686-689. https:// doi.org/10.26444/aaem/99054

58. Buczek A, Bartosik K, Buczek AM, Buczek W, Stanko M. Conspecific hyperparasitism in the Hyalomma excavatum tick and considerations on the biological and epidemiological implications of this phenomenon. Ann Agric Environ Med. 2019; 26(4): 548-554. https:// doi.org/10.26444/aaem/110128 
59. Votava CL, Rabalais FC, Ashley DC. Transmission of Dipetalonema viteae by hyperparasitism in Ornithodorus tartakovskyi. J Parasitol. 1974; 60(3): 479

60. Helmy N, Khalil GM, Hoogstraal H. Hyperparasitism in Ornithodoros erraticus. J Parasitol. 1983; 69(1): 229-233.

61. Alekseev AN, Dubinina HV. Exchange of Borrelia burgdorferi between Ixodes persulcatus (Ixodidae: Acarina) sexual partners. J Med Entomol. 1996; 33(3): 351-354.

62. Márquez FJ, Rojas A, Ibarra V, Cantero A, Rojas J, Oteo JA, Muniain MA. Prevalence data of Rickettsia slovaca and other SFG Rickettsiae species in Dermacentor marginatus in the southeastern Iberian peninsula. Ann NY Acad Sci. 2006; 1078: 328-330.

63. Oteo JA, Portillo A, Santibáñez S, Pérez-Martínez L, Blanco JR, Jiménez S, Ibarra V, Pérez-Palacios A, Sanz M. Prevalence of spotted fever group Rickettsia species detected in ticks in La Rioja, Spain. Ann NY Acad Sci. 2006; 1078: 320-323.

64. Obiegala A, Król N, Oltersdorf C, Nader J, Pfeffer M. The enzootic lifecycle of Borrelia burgdorferi (sensu lato) and tick-borne rickettsiae: an epidemiological study on wild-living small mammals and their ticks from Saxony, Germany. Parasit Vectors. 2017; 10: 115. https://doi. org/10.1186/s13071-017-2053-4

65. Didyk YM, Blaňárová L, Pogrebnyak S, Akimov I, Pet'ko B, Víchová B. Emergence of tick-borne pathogens (Borrelia burgdorferi sensu lato, Anaplasma phagocytophilum, Ricketsia raoultii and Babesia microti) in the Kyiv urban parks, Ukraine. Ticks Tick Borne Dis. 2017; 8(2): 219-225. https://doi.org/10.1016/j.ttbdis.2016.10.002

66. Pluta S, Hartelt K, Oehme R, Mackenstedt U, Kimmig P. Prevalence of Coxiella burnetii and Rickettsia spp. in ticks and rodents in southern Germany. Ticks Tick Borne Dis. 2010; 1(3): 145-147.

67. Burri C, Schumann O, Schumann C, Gern L. Are Apodemus spp. mice and Myodes glareolus reservoirs for Borrelia miyamotoi, Candidatus Neoehrlichia mikurensis, Rickettsia helvetica, R. monacensis and Anaplasma phagocytophilum? Ticks Tick Borne Dis. 2014; 5(3): 245 251.

68. Minichová L, Hamšíková Z, Mahríková L, Slovák M, Kocianová E, Kazimírová M, Škultéty L, Štefanidesová K, Špitalská E. Molecular evidence of Rickettsia spp. in ixodid ticks and rodents in suburban, natural and rural habitats in Slovakia. Parasit Vectors. 2017; 10: 158. https://doi.org/10.1186/s13071-017-2094-8

69. Baráková I, Derdáková M, Selyemová D, Chvostáč M, Špitalská E, Rosso F, Collini M, Rosà R, Tagliapietra V, Girardi M, Ramponi C, Hauffe HC, Rizzoli A. Tick-borne pathogens and their reservoir hosts in northern Italy. Ticks Tick Borne Dis. 2018; 9(2): 164-170. https:// doi.org/ 10.1016/j.ttbdis.2017.08.012

70. Heglasová I, Víchová B, Kraljik J, Mošanský L, Miklisová D, Stanko M. Molecular evidence and diversity of the spotted-fever group Rickettsia spp. in small mammals from natural, suburban and urban areas of Eastern Slovakia. Ticks Tick Borne Dis. 2018; 9(6): 1400-1406. https:// doi.org/10.1016/j.ttbdis.2018.06.011

71. Olivieri E, Wijnveld M, Bonga M, Berger L, Manfredi MT, Veronesi F, Jongejan F. Transmission of Rickettsia raoultii and Rickettsia massiliae DNA by Dermacentor reticulatus and Rhipicephalus sanguineus (s.1.) ticks during artificial feeding. Parasit Vectors. 2018; 11: 494. https:// doi.org/10.1186/s13071-018-3075-2

72. Gajda E, Hildebrand J, Sprong H, Buńkowska-Gawlik K, PerecMatysiak A, Coipan EC. Spotted fever rickettsiae in wild-living rodents from south-western Poland. Parasit Vectors. 2017; 10: 413. https://doi. org/10.1186/s13071-017-2356-5

73. Ortuño A, Quesada M, López-Claessens S, Castellà J, Sanfeliu I, Antón E, Segura-Porta F. The role of wild boar (Sus scrofa) in the eco-epidemiology of $R$. slovaca in Northeastern Spain. Vector Borne Zoonotic Dis. 2007; 7(1): 59-64. https://doi.org/10.1089/vbz.2006.0576

74. Chisu V, Foxi C, Masala G. First molecular detection of the human pathogen Rickettsia raoultii and other spotted fever group rickettsiae in Ixodid ticks from wild and domestic mammals. Parasitol Res. 2018; 117(11): 3421-3429. https://doi.org/10.1007/s00436-018-6036-y

75. Schreiber C, Krücken J, Beck S, Maaz D, Pachnicke S, Krieger K, Gross M, Kohn B, von Samson-Himmelstjerna G. Pathogens in ticks collected from dogs in Berlin/Brandenburg, Germany. Parasit Vectors. 2014; 7: 535. https://doi.org/10.1186/s13071-014-0535-1

76. Wächter M, Wölfel S, Pfeffer M, Dobler G, Kohn B, Moritz A, Pachnicke S, Silaghi C. Serological differentiation of antibodies against Rickettsia helvetica, $R$. raoultii, $R$. slovaca, $R$. monacensis and $R$. felis in dogs from Germany by a micro-immunofluorescent antibody test. Parasit Vectors. 2015; 8: 126. https://doi.org/10.1186/s13071-015-0745-1

77. Ortuño A, Pons I, Quesada M, Lario S, Anton E, Gil A, Castellà J, Segura F. Evaluation of the presence of Rickettsia slovaca infection in domestic ruminants in Catalonia, Northeastern Spain. Vector Borne Zoonotic Dis. 2012; 12(12): 1019-1022. https://doi.org/10.1089/ vbz.2012.0972

78. Lakos A, Körösi A, Földvári G. Contact with horses is a risk factor for tick-borne lymphadenopathy (TIBOLA): a case control study. Wien Klin Wochenschr. 2012; 124(17-18): 611-617. https://doi.org/10.1007/ s00508-012-0217-y

79. Földvári G, Rigó K, Lakos A. Transmission of Rickettsia slovaca and Rickettsia raoultii by male Dermacentor marginatus and Dermacentor reticulatus ticks to humans. Diagn Microbiol Infect Dis. 2013; 76(3): 387-389. https://doi.org/10.1016/j.diagmicrobio.2013.03.005

80. Bullová E, Lukán M, Stanko M, Petko B. Spatial distribution of Dermacentor reticulatus tick in Slovakia in the beginning of the 21st century. Vet Parasitol. 2009; 165(3-4): 357-360. https://doi. org/10.1016/j.vetpar.2009.07.023

81. Chitimia-Dobler L. Spatial distribution of Dermacentor reticulatus in Romania. Vet Parasitol. 2015; 214(1-2): 219-223. https://doi. org/10.1016/j.vetpar.2015.09.018

82. Földvári G, Široký P, Szekeres S, Majoros G, Sprong H. Dermacentor reticulatus: a vector on the rise. Parasit Vectors. 2016; 9: 314. http:// dx.doi.org/10.1186/s13071-016-1599-x

83. Hofmeester TR, van der Lei PB, Docters van Leeuwen A, Sprong H, van Wieren SE. New foci of Haemaphysalis punctata and Dermacentor reticulatus in the Netherlands. Ticks Tick Borne Dis. 2016; 7(2): 367370. https://doi.org/10.1016/j.ttbdis.2015.12.009

84. Rubel F, Brugger K, Pfeffer M, Chitimia-Dobler L, Didyk YM, Leverenz S, Dautel H, Kahl O. Geographical distribution of Dermacentor marginatus and Dermacentor reticulatus in Europe. Ticks Tick Borne Dis. 2016; 7(1): 224-233. https://doi.org/10.1016/j.ttbdis.2015.10.015

85. Walter M, Brugger K, Rubel F. The ecological niche of Dermacentor marginatus in Germany. Parasitol Res. 2016; 115(6): 2165-2174. https:// doi.org/10.1007/s00436-016-4958-9

86. Selmi M, Tomassone L, Ceballos LA, Crisci A, Ragagli C, Pintore MD, Mignone W, Pautasso A, Ballardini M, Casalone C, Mannelli A. Analysis of the environmental and host-related factors affecting the distribution of the tick Dermacentor marginatus. Exp Appl Acarol. 2018; 75(2): 209-225. https://doi.org/10.1007/s10493-018-0257-8

87. Buczek A, Zając Z, Woźniak A, Kulina D, Bartosik K. Locomotor activity of adult Dermacentor reticulatus ticks (Ixodida: Ixodidae) in natural conditions. Ann Agric Environ Med. 2017; 24(2): 271-275. https://doi.org/10.5604/12321966.1230736

88. Kagemann J, Clay K. Effects of infection by Arsenophonus and Rickettsia bacteria on the locomotive ability of the ticks Amblyomma americanum, Dermacentor variabilis, and Ixodes scapularis. J Med Entomol. 2013; 50(1): 155-162.

89. El Nabbout A, Kho J, Lloyd V, Rossolimo T. Rickettsia spp. and its Effects on the physiology and behaviour of Dermacentor variabilis. Int J Biol. 2017; 9(2): 39-49. https://doi.org/10.5539/ijb.v9n2p39

90. Siuda K. 1993. Ticks (Acari: Ixodida) of Poland. Part II Taxonomy and Distribution. PTP, Warszawa (in Polish).

91. Buczek A, Kuśmierz A, Olszewski K, Buczek L, Czerny K, Łańcut M. Comparison of rabbit skin changes after feeding of Ixodes ricinus (L.) and Dermacentor reticulatus (Fabr.), In: Bernini F, Nannelli R, Nuzzaci G, de Lillo E. (Eds.), Acarid phylogeny and evolution: adaptation in mites and ticks. Proceedings of the IV Symposium of the European Association of Acarologists. Kluwer Academic Publ., Dordrecht, 2002, pp. 419-424.

92. Buczek A, Bartosik K. Ticks (Ixodida: Ixodidae, Amblyommidae) in south-eastern Poland and their medical and epidemiological importance. Zdr Publ. 2011; 121(4): 392-397.

93. Zając Z, Bartosik K, Buczek A. Factors influencing the distribution and activity of Dermacentor reticulatus (F.) ticks in an anthropopressure unaffected area in central-eastern Poland. Ann Agric Environ Med. 2016; 23(2): 270-275. https://doi.org/10.5604/12321966.1203889

94.Zygner W, Wędrychowicz H. Occurrence of hard ticks in dogs from Warsaw area. Ann Agric Environ Med. 2006; 13(2): 355-359.

95.Zygner W, Górski P, Wędrychowicz H. New localities of Dermacentor reticulatus tick (vector of Babesia canis canis) in central and eastern Poland. Pol J Vet Sci. 2009; 12(4): 549-555.

96. Kadulski S, Izdebska JN. New data on distribution of Dermacentor reticulatus (Fabr.) (Acari, Ixodidae) in Poland, In: Buczek A, Błaszak C. (Eds.), Arthropods: Invasions and their control. Akapit, Lublin, 2009 , pp. 53-58.

97. Mierzejewska EJ, Estrada-Peña A, Alsarraf M, Kowalec M, Bajer A Mapping of tick Dermacentor reticulatus expansion in Poland in 2012-2014. Ticks Tick Borne Dis. 2016; 7(1): 94-106. https://doi. org/10.1016/j.ttbdis.2015.09.003 
98. Karbowiak G, Kiewra D. New locations of Dermacentor reticulatus ticks in Western Poland: the first evidence of the merge in D. reticulatus occurrence areas? Wiad Parazytol. 2010; 56(4): 333-336.

99. Nowak M. Discovery of Dermacentorreticulatus(Acari:Amblyommidae) populations in the Lubuskie Province (Western Poland). Exp Appl Acarol. 2011; 54(2): 191-197. https://doi.org/10.1007/s10493-010-9422-4

100. Kiewra D, Czulowska A. Evidence for an increased distribution range of Dermacentor reticulatus in south-west Poland. Exp Appl Acarol. 2013; 59(4): 501-506. https://doi.org/10.1007/s10493-012-9612-3

101. Cuber P, Solarz K, Mosiałek A, Jakubiec-Spanier M, Spanier A. The first record and occurrence of the ornate cow tick Dermacentor reticulatus (Fabricius, 1794) in south-western Poland. Ann Parasitol. 2013; 59(1): 49-51.

102. Gray JS, Dautel H, Estrada-Peña A, KahlO, Lindgren E. Effects of climate change on ticks and tick-borne diseases in Europe. Interdiscip Perspect Infect Dis. 2009; 593232: 1-12. https://doi.org/10.1155/2009/593232

103. Buczek A, Bartosik K, Zajac Z. Changes in the activity of adult stages of Dermacentor reticulatus (Ixodida: Amblyommidae) induced by weather factors in eastern Poland. Parasit Vectors. 2014; 7: 245. https:// doi.org/10.1186/1756-3305-7-245

104.Kiewra D, Czulowska A, Lonc E. Winter activity of Dermacentor reticulatus (Fabricius, 1794) in the newly emerging population of Lower Silesia, south-west Poland. Ticks Tick Borne Dis. 2016; 7(6): 1124-1127. https://doi.org/10.1016/j.ttbdis.2016.08.012

105. Buczek A, Bartosik K, Wiśniowski Ł, Tomasiewicz K. Changes in population abundance of adult Dermacentor reticulatus (Acari: Amblyommidae) in long-term investigations in eastern Poland. Ann Agric Environ Med. 2013; 20(2): 269-272.

106. Bartosik K, Wiśniowski Ł, Buczek A. Abundance and seasonal activity of adult Dermacentor reticulatus (Acari: Amblyommidae) in eastern Poland in relation to meteorological conditions and the photoperiod. Ann Agric Environ Med. 2011; 18(2): 340-344.

107. Bartosik K, Wiśniowski Ł, Buczek A. Questing behavior of Dermacentor reticulatus adults (Acari: Amblyommidae) during diurnal activity periods in eastern Poland. J Med Entomol. 2012; 49(4): 859-864.

108. Buczek A, Bartosik K, Zając Z, Stanko M. Host-feeding behaviour of Dermacentor reticulatus and Dermacentor marginatus in monospecific and inter-specific infestations. Parasit Vectors. 2015; 8: 470. https://doi.org/10.1186/s13071-015-1078-9

109. Bartosik K, Buczek A, Borzęcki A, Kulina D. Study of the non-parasitic stage in Ixodes ricinus after co-feeding with Dermacentor reticulatus in three infestations. Ann Agric Environ Med. 2017; 24(1): 90-95. https:// doi.org/10.5604/12321966.1234005

110. Bartosik K, Buczek A. The impact of intensity of invasion of Ixodes ricinus and Dermacentor reticulatus on the course of the parasitic phase. Ann Agric Environ Med. 2012: 19(4): 651-655.

111. Bartosik K, Buczek A, Buczek W, Buczek AM, Kulina D, Koman-Iżko A. Host feeding behaviour of Dermacentor reticulatus males in relation to the transmission of pathogens. Ann Agric Environ Med. 2019; 26(2): 227-230. https://doi.org/10.26444/aaem/105402.

112. Mittermayer T, Brezina R, Urvölgyi J. First report of an infection with Rickettsia slovaca. Folia Parasitol. 1980; 27(4): 373-376.

113. Raoult D, Berbis P, Roux V, Xu W, Maurin M. A new tick-transmitted disease due to Rickettsia slovaca. Lancet 1997; 350(9071): 112-113. https://doi.org/10.1016/S0140-6736(05)61814-4
114. Bacellar F, Núncio MS, Alves MJ, Filipe AR. Rickettsia slovaca: un agente del grupo de las fiebres exantemáticas, en Portugal. Enferm Infecc Microbiol Clin. 1995; 13(4): 218-223.

115. Komitova R, Lakos A, Aleksandrov A, Christova I, Murdjeva M. A case of tick-transmitted lymphadenopathy in Bulgaria associated with Rickettsia slovaca. Scand J Infect Dis. 2003; 35(3): 213. https:// doi.org/10.1080/0036554021000027016

116. Parola P, Rovery C, Rolain JM, Brouqui P, Davoust B, Raoult D. Rickettsia slovaca and $R$. raoultii in tick-borne rickettsioses. Emerg Infect Dis. 2009; 15(7): 1105-1108. https://doi.org/10.3201/eid1507.081449

117. Rieg S, Schmoldt S, Theilacker C, de With K, Wölfel S, Kern WV, Dobler G. Tick-borne lymphadenopathy (TIBOLA) acquired in Southwestern Germany. BMC Infect Dis. 2011; 11: 167. https://doi.org/10.1186/14712334-11-167

118. Sekeyova Z, Subramanian G, Mediannikov O, Diaz MQ, Nyitray A, Blaskovicova H, Raoult D. Evaluation of clinical specimens for Rickettsia, Bartonella, Borrelia, Coxiella, Anaplasma, Franciscella and Diplorickettsia positivity using serological and molecular biology methods. FEMS Immunol Med Microbiol. 2012; 64(1): 82-91. https:// doi.org/ 10.1111/j.1574-695X.2011.00907.x

119. Świtaj K, Chmielewski T, Borkowski P, Tylewska-Wierzbanowska S, Olszynska-Krowicka M. Spotted fever rickettsiosis caused by Rickettsia raoultii-case report. Przegl Epidemiol. 2012; 66(2): 347-350.

120.Chmielewski T, Rudzka D, Fiecek B, Mączka I, Tylewska-Wierzbanowska S. Case of TIBOLA/DEBONEL (tick-borne lymphadenopathy/ Dermacentor-spp. borne necrosis-erythema lymphadenopathy) in Poland. Przegl Epidemiol. 2011; 65(4): 583-586.

121. Nilsson K, Liu A, Pahlson C, Lindquist O. Demonstration of intracellular microorganisms (Rickettsia spp., Chlamydia pneumoniae, Bartonella spp.) in pathological human aortic valves by PCR. J Infect. 2005; 50(1): 46-52.

122.Zajac V, Wojcik-Fatla A, Cisak E, Sroka J, Sawczyn A, Dutkiewicz J. Study on tick-borne rickettsiae in eastern Poland. II. Serological response of occupationally exposed populations. Ann Agric Environ Med. 2013; 20(2): 280-282.

123. Antón E, Nogueras MM, Pons I, Font B, Muñoz T, Sanfeliu I, Segura F. Rickettsia slovaca infection in humans in the northeast of Spain: seroprevalence study. Vector Borne Zoonotic Dis. 2008; 8(5): 689-694. https://doi.org/10.1089/vbz.2007.0246

124.Lledó L, Gegúndez MI, Fernandes N, Sousa R, Vicente J, Alamo R, Fernández-Soto P, Pérez-Sánchez R, Bacellar F. The seroprevalence of human infection with Rickettsia slovaca, in an area of northern Spain. Ann Trop Med Parasitol. 2006; 100(4): 337-343.

125. Fournier PE, Xeridat B, Raoult D. Isolation of a rickettsia related to Astrakhan fever rickettsia from a patient in Chad. Ann NY Acad Sci. 2003; 990: 152-157.

126.Portillo A, Santibáñez S, García-Álvarez L, Palomar AM. Rickettsioses in Europe. Microbes Infect. 2015; 17(11-12): 834-838. https://doi. org/10.1111/j.1749-6632.2003.tb07356.x

127. Dubourg G, Socolovschi C, Del Giudice P, Fournier PE, Raoult D. Scalp eschar and neck lymphadenopathy after tick bite: an emerging syndrome with multiple causes. Eur J Clin Microbiol Infect Dis. 2014; 33(8): 1449-1456. http://dx.doi.org/10.1007/s10096-014-2090-2

128. Nilsson K, Lindquist O, Pahlso C. Association of Rickettsia helvetica with chronic perimyocarditis in sudden cardiac death. Lancet 1999; 354(9185): 1169-1173. 